\title{
The Effectiveness and Efficiency of the Police Service Model at the Border of Indonesia and Timor Leste
}

\author{
Dominicus S. Yempormase ${ }^{\star} \quad$ Fredrick L Benu David B.W Pandie \\ Postgraduate Program in Public Administration, Nusa Cendana University, PO BOX 104 Kupang, \\ East Nusa Tenggara
}

\begin{abstract}
The purpose of this study is to show the concept of effective and efficient services for the police service function at the border between the Republic of Indonesia and the Democratic Timor Leste. This study uses a mixed research method (mix method). The data obtained quantitatively are then described qualitatively. The number of samples was determined using the Slovin equation, as many as 100 respondents, while the composition of the sample was obtained through the strata field sampling technique. Quantitative data obtained through a questionnaire, analyzed using the community satisfaction index approach and then tested statistically with t test paired sample $t$ test, while the effectiveness and efficiency of services were analyzed descriptively. The results of hypothesis testing with the $\mathrm{t}$ test show that the working hypothesis is accepted, that is, there are significant differences when using the combined service model (online) and the standard service model (conventional). The significant difference is also shown by the increase in the community satisfaction index when using the online service model by $66.32 \%$ compared to using the conventional service model of $60.52 \%$. The results of the discussion conclude that the online service model is feasible because it can increase the quality of police services effectively and efficiently.
\end{abstract}

Keywords: Border, Challenge effectiveness, Efficiency, Police, Service

DOI: $10.7176 /$ PPAR/10-9-11

Publication date:September $30^{\text {th }} 2020$

\section{Introduction}

The duties and responsibilities to maintain the security of the State are the duties and responsibilities of all citizens of the Republic of Indonesia, and in terms of security is under the control of the Indonesian National Police (Polri). This is in accordance with Article 2 of Law No. 2 of 2002 on the Indonesian National Police (Presiden RI, 2002). In this law, one of the articles states that the maintenance of domestic security through efforts to carry out police functions which include public order, law enforcement, protection, protection, and service to the public is carried out by the State Police of the Republic of Indonesia as a state apparatus assisted by the community by upholding the human rights, therefore the application of service delivery must be given special attention because it involves the Indonesian people's rights.

Polri's concrete steps to optimize its function and role in the field of security services to the community are also part of the reform of the Bureaucracy, one of which aims to serve the community, carried out in all Polri institutions from the National Police headquarters to the Sub-Sector Police Unit (Sub-sector Pols), including the East Nusa Tenggara Regional Police (Polda NTT).

The service model that has been implemented so far in a service unit called the Integrated Police Service Unit (SPKT) still leaves a lot of homework to do. Optimization of the elements of the implementation of service tasks to the community in 21 Polres in the NTT Regional Police Legal Area has so far only reached 63\%. The SPKT service is institutionally implemented in all areas of the Indonesian Police, including the NTT Regional Police. Of the 21 Polres in the NTT Polda jurisdiction, there are 4 Polres which are geographically facing the Democratic Republic of Timor Leste (RDTL), namely the Belu Police, the TTU Polres, the Kupang Polres and the Malacca Polres (Polres Baru) .

Referring to the NTT Ombudsman report in 2020, information was obtained that out of 4 Polres on the border, 3 Polres are on the Yellow zone, namely Polres Belu, Polres Malacca, and Polres Kupang. While the other 1, the Polres Kupang, is on the red zone. This fact shows that the police service in border areas is still not optimal and needs serious attention (Daton, 2020).

In an effort to achieve good service quality, it is necessary to formulate public service standards that can be used as benchmarks for quality service. Public service standards by the Police of the Republic of Indonesia are stipulated in the SOP of the Integrated Police which is the standard to be implemented from the central level to the Polsek level throughout the Unitary Territories of the Republic of Indonesia.

The decision of the National Police to improve the quality of service has not been effectively implemented until the Sub-sector Police unit, because the service model carried out is a wait and see service model. This means that when there is a report, it responds when there is nothing else demanding the Police's roles, therefore, the Polri's service function becomes stagnant. This is exacerbated by various barriers, namely wide geographical conditions, limited personnel, lack of infrastructure and apathetic and safe-seeking behavior in carrying out security duties in their respective areas. 
The success in implementing the principle of quality service is highly dependent on the process of public services being carried out and the effectiveness and efficiency of the resulting services. In connection with the process of public services in the RI-RDTL border area which is not yet effective and efficient, it is identified that there are several factors that hinder it, including organizational factors, lack of capacity and quality of the apparatus, inadequate service systems and inadequate infrastructure and infrastructure that are not yet supported.

One of the strategies taken by border Polres to approach the services by dealing with various limitations of personnel, facilities and geographical conditions is to develop forms of service by utilizing technology. According to Warren Bennis and Michael Mische (in Mulyadi, 2015), that this technological resource engineering process is the embodiment and development of technology carried out to support organizational tasks and functions, the use of technology referred to is to achieve the effectiveness and efficiency in all types of services provided by the Police.

The technology used as an extension tool for the police to make services more efficient and efficient for the people in border areas is to use information system technology (SIM) based on website services. The website that has been built is a partial website, meaning that it only contains information services and feedback on information provided and information received. In this case the public will provide information of a service and the police will respond in the form of information or in the form of documents needed by the community. The information system developed by the Police at the border is not designed to replace the function and role of direct police services to the community, but in operation it is used as a companion to optimize services for both service providers and service recipients.

This study aims to determine the index of community satisfaction with the quality of security services carried out by the National Police, especially the police services at the border of the Republic of Indonesia and RDTL. This research also intends to reveal the effectiveness and efficiency of the police service model for communities at the border of Indonesia and Timor Leste.

\section{Literature Review}

\subsection{Polri}

The Police of the Republic of Indonesia (Polri) is a state institution established to carry out security and order functions for the community. Charles Reith (in Anton, 2002) states that in carrying out their duties, the police are required to protect the community, but on the other hand the police can also take legal action against criminals, or in other words, the National Police in addition to carry out a preventive function as well the function of law enforcement. According to Hermawan (2016), the main duties of the police are Crime control (crime control), Order maintenance (maintaining order) and, Service provision (service providers). Bayley (1986) emphasizes that the police must give operational priority to serve community and to met their needs. The needs of the people that must be served by the police in Indonesia are spread throughout the territory of Indonesia, including to the border of the Republic of Indonesia and the State of Democratic Timor Leste.

In order to ensure the implementation of the police's duties in the Republic of Indonesia, in accordance with the Regulation of the Head of the National Police of the Republic of Indonesia, Regulation of the Chief of Police of the Republic of Indonesia Number 23 of 2010 concerning Organizational Structure and Work Procedures at the Resort Police and Sector Police levels emphasizes to optimize the service functions of the police from the highest level, namely Polda to a police unit at the lowest level (police post) is formed SPKT (Integrated Police Service Center) which has a special task of providing police services to the community (Kapolri, 2020). The form of police service which is under the authority of the SPKT consists of Police Reports, Police Report Receipts, Notifications on the Progress of Investigation Results, Certificate of Lost Report, Certificate of Police Records, Notification Receipt, Self-Report Certificate, Crowd Permit, Letter Recommendations for Observation Services Business Permits, Driving Permits and Motor Vehicle Numbers .

\subsection{Public Services}

Zauhar (2007) defines that public service is an effort to help or provide benefits to the public through the provision of goods and or services needed by the community. The meaning of public service in the framework of security and public order (Public safety), according to Hermawan (2016), is more intended as a provision of public service by the police in the community by providing guidance (providing guidance) individually or collectively in protecting their environment. Furthermore, according to Hermawan (2016) one of the principles of the New Public Service (NPS) is actually to re-place the public interest as the center of attention in government services.

In the context of this research, the Polri Institution at various levels from the National Police to the police post tries to establish itself as a government institution that provides security services to the public by placing the interests and needs of the community as the center of their service.

\subsection{Effectivity and Efficiency}

Effective is the results that are in accordance with the stated objectives, by using certain amounts of resources, 
facilities and infrastructure to consciously produce a number of goods for the services of the activities it carries out. Luas et al. (2017) state that the level of effectiveness can be measured by comparing the predetermined plans or targets with the results achieved, then the effort or the results of the work is said to be effective, but if the effort or work done is not achieved in accordance with what was planned, it is said to be ineffective. Furthermore, Luas et al. (2017) mention 3 (three) main approaches in measuring organizational effectiveness, namely: 1) The resource approach, which measures the effectiveness of the input;2) The process approach is to see the extent to which the effectiveness of program implementation of all internal activities or organizational mechanisms; and 3. The goal approach is where the focus is on the output, measuring the success of the organization in achieving the results (output) according to the plan. This approach measures the extent to which an institution has succeeded in realizing its goals to be achieved. The goals that are important to consider in measuring effectiveness with this approach are realistic goals to provide maximum results based on the official goal. Makmur (2011) states that the effectiveness indicators are seen from several aspects of effectiveness criteria, which are, timeliness, accuracy in cost calculations, accuracy in measurement, accuracy in making choices, accuracy in thinking, accuracy in carrying out orders, accuracy in determining goals and target accuracy.

Meanwhile, efficiency is known as the ratio between input and output. Basuki (2018) describes efficiency as the best comparison between a job and its results. Efficiency in work is the best comparison between a job and the results achieved by that work. Mahmudi (2005) emphasizes that efficiency is related to the relationship between output in the form of goods or services produced and the resources used to produce these outputs. An organization, program, or activity is said to be efficient if it is able to produce certain outputs with the lowest input, or with certain inputs it is able to produce the maximum output (spending well). Liliweri (2014) describes the concept of effectiveness and efficiency as an inseparable part, even becoming the ideals and goals of organizational achievements. Every organization always tries, with all its resources, so that the goals and ideals in organizational planning can be achieved effectively and efficiently. Effectiveness and efficiency in the context of this study are interpreted as the level of achievement of the objectives of the National Police organization as a public servant, to minimize the use of resources as the input to produce security services for the community.

\section{Research Methods}

This research is using a combined method, namely quantitative research and qualitative research or what is known as a mixed method. Sugiyono (2012) states that the combined research method (mixed methods) is a research method that combines quantitative methods with qualitative methods in a research activity, so the results are more comprehensive, valid, reliable and objective.

The sample was determined using the Slovin formula, with the number of polls being the total population of 10 RI-RDTL border police as many as 178,762 people. By using a standard error of $10 \%$, the number of samples obtained is:

$$
n=\frac{N}{1+N e^{2}}=\frac{178762}{1+\left(178762 \times 0.1^{2}\right)}=\frac{178762}{1788.62}=99.94 \sim 100
$$

The samples on the questionnaire were determined by accidental time. This technique was chosen due to geographical conditions and the difficulty of finding people (respondents) who would like to seek services at the nearest police station.

Based on data collected through a questionnaire, then analyzed in reference to:

\subsection{Effectiveness and Efficiency of Police services}

Police service is carried out by comparing the standard service model (conventional) and the combined service model (online). The effectiveness and efficiency of border police services were statistically analyzed with a correlation t-test.

$$
t=\frac{\overline{X_{1}}-\bar{X}_{2}}{\sqrt{\frac{s_{1}^{2}}{n_{1}}+\frac{s_{2}^{2}}{n_{2}}-2 r\left\{\frac{s_{1}}{\sqrt{n_{1}}}\right\}\left\{\frac{s_{2}}{\sqrt{n_{2}}}\right\}}} \ldots
$$

The hypothesis being tested is there are significant differences in effectiveness and efficiency between the conventional model and the online model.

\subsection{Analysis of the Satisfaction Index of Police Services}

The analysis of the community satisfaction index for police services was carried out to confirm that the effectiveness and efficiency of the services that occurred on the two service models provided were able to provide service satisfaction to communities at the border. The stages of testing the satisfaction index for police services at the border are carried out in stages:

a. Determine the average value per service element

$$
\text { Average Value }=\frac{\text { Service Value }}{\text { Total Respondents }} . .
$$


b. Determining the Community Satisfaction Index (CSI)

Based on PermenPAN Number: Kep / 25 / M.PAN / 2/2004, it states that the number of service elements is 14 (Menteri PAN, 2004).

$$
\text { Average Value }=\frac{\text { Service Value }}{\text { Total Respondents }}
$$

c. Determine the Interpretation of the Community Satisfaction Index level

CSI Service Units $\times 25$... (4)

Table 1. Perceived value, interval IKM, IKM interval conversion. service quality and service unit performance

\begin{tabular}{|l|l|l|l|l|}
\hline $\begin{array}{c}\text { Perceived } \\
\text { Value }\end{array}$ & \multicolumn{1}{|c|}{ CSI Internal Value } & \multicolumn{1}{|c|}{ CSI Interval Conversion } & Service Quality & \multicolumn{1}{|c|}{$\begin{array}{c}\text { Service Unit } \\
\text { Performance }\end{array}$} \\
\hline 1 & $1.00-1.75$ & $25-43.75$ & D & Very bad \\
\hline 2 & $1.76-2.50$ & $43.76-62.50$ & C & Poor \\
\hline 3 & $2.51-3.25$ & $62.51-81.25$ & B & Good \\
\hline
\end{tabular}

Source : PermenPAN Nomor : Kep/25/M.PAN/2/2004

\section{Results and Review}

\subsection{Results}

4.1.1 Effectiveness and efficiency of the police service model

Table 2. Results of service model effectiveness and efficiency tests

\begin{tabular}{|c|c|c|c|c|c|c|c|}
\hline & \multicolumn{3}{|c|}{ Paired Differences } & \multirow[b]{2}{*}{$\mathrm{t}$} & \multirow[b]{2}{*}{$\mathrm{df}$} & \multirow[b]{2}{*}{$\begin{array}{l}\text { Sig. (2- } \\
\text { tailed) }\end{array}$} \\
\hline & & Mean & $\begin{array}{l}\text { Std. } \\
\text { Deviation }\end{array}$ & $\begin{array}{l}\text { Std. Error } \\
\text { Mean }\end{array}$ & & & \\
\hline Pair 1 & $\begin{array}{l}\text { Conventional } \\
\text { Service Model - } \\
\text { Integrated Service } \\
\text { Model }\end{array}$ & 4.1862 & .48113 & .17010 & 24.610 & 99 & .000 \\
\hline
\end{tabular}

The results of the analysis of the t-paired sample $t$ test in the table above states that the $t$ value is 24,610 with a probability value of sig. ( 2 tailed) $(\rho)$ of 0.000 . The conditions of the hypothesis is if the value of $t$ count $>t$ table and the value of sig. $<0.05$. The calculated values above show that the proposed hypothesis is accepted, that is, there are significant differences in effectiveness and efficiency between the conventional model and the online model.

4.1.2 Index of Community Satisfaction on Performance of Police Services at the border

a. Average value per service element

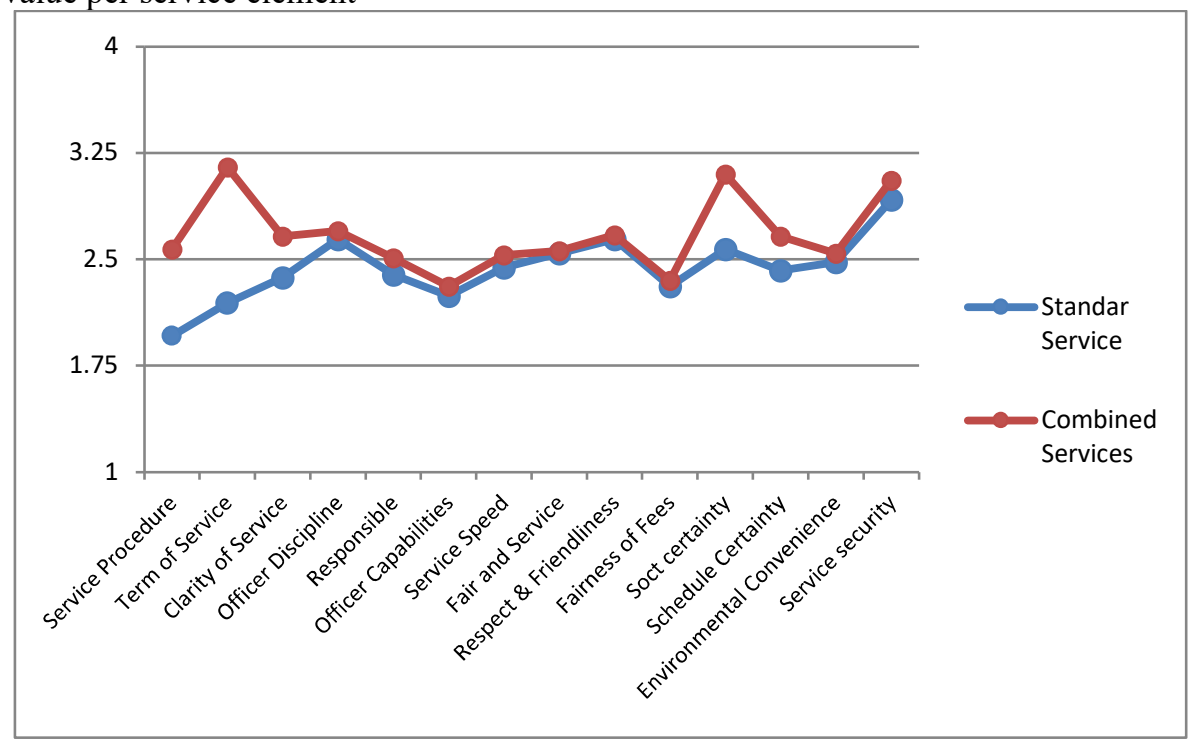

Figure 1. Graph of Average Element Value per Service Unit

Based on the graph, it is known that the average element value per service unit above is still using the standard (conventional) service model in which there are 8 elements out of 14 elements of police service that have poor scores, namely service procedures, service requirements, service clarity, and officer responsibility, the speed of service, unreasonable costs, uncertainty of service schedules and the comfort of the environment at the service 
location. When using the combined service model (online) which is supported by the use of a website-based service system, there is a decrease in dissatisfaction with the implementation of the elements of police service so that only 2 aspects still get red report cards, namely the capability of the officers and fairness of costs.

b. Community satisfaction index (CSI)

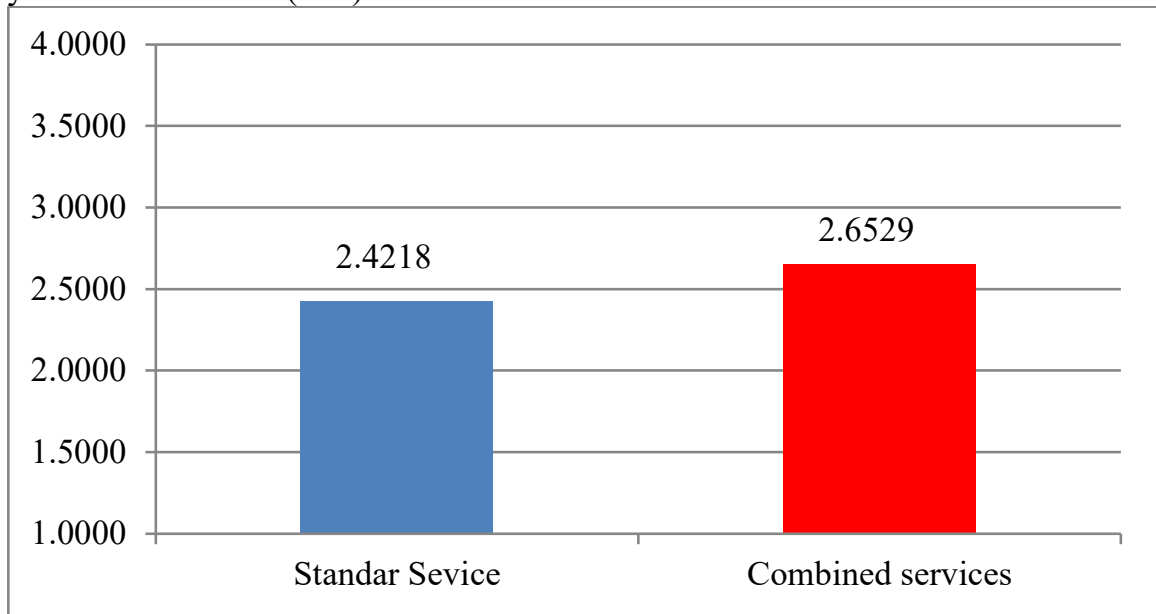

Figure 2. Average

c. Interpretation of Community Satisfaction Index Levels

$$
\begin{array}{cc}
\text { CSI (Standard) } & \text { IM Service Units x Primary Value } \\
& =2.421 \times 25=60.53 . \\
\text { CSI (Combined) } & =\text { IM Service Units } \times \text { Primary Value } \\
= & 2.6529 \times 25=66.32 .
\end{array}
$$

From these calculations, it is known that the value of the Community Satisfaction Index at the SPKT service of the RI - RDTL border police at the NTT Regional Police while still using the standard service model is in the "poor" category because the value is between 43.76 - 62.50 value intervals which are at service quality C (Not good). However, after using the combined service system (online), the community satisfaction index value increased to 66.32 or was in the Good category.

\subsection{Discussion}

The public services provided by the Police of the Republic of Indonesia to the public in the field of security services are a demonstration of the functions of the state apparatus as public servants. As one of the state institutions that provide public services, the National Police Organization from the central to regional levels implements the concept of public services in accordance with the Minister of Agriculture Decree Number 81 of 1993, which in its implementation, the services provided must contain the following elements: first, rights and the obligations for the government and public service recipients must be clear and known with certainty by each party. Second, the regulation of every form of public service must be adjusted to the conditions of the public's need and capacity to pay, based on the provisions of the prevailing laws and regulations while still adhering to efficiency and effectiveness (Menteri PAN, 1993). Third, the quality, process and results of public services must be endeavored to provide security, comfort, smoothness and legal certainty that can be accounted for. Fourth, if public services provided by government agencies are forced to be expensive, the government affiliated with is obliged to provide opportunities for the public to participate in organizing it in accordance with the prevailing laws and regulations.

In order to optimize the performance of police services, the National Police has formed an integrated police service unit (SPKT) which is regulated in Law No. 2 of 2002 and Perkap No. 22/2010 (Kapolri, 2020). Integrated Police Service Center (SPKT) in Territorial Unity, is an element of executing the main task in providing integrated services to the community at Polda, Polres and Polsek levels. The main task of the SPKT is to provide integrated police services to the community in various forms of activities, with the main principle being to provide effective and efficient police services.

The concept of effectiveness has a very varied meaning with its main focus on different evaluation criteria being carried out simultaneously. Monoarfa (2012) states that effectiveness is a measure of the success or failure of achieving organizational goals. If an organization has succeeded in achieving its goals, then the organization has been running effectively. Meanwhile, efficiency is seen as a form of saving on the effectiveness function that has been carried out by the organization. The problem of service from the aspect of effectiveness at the border is very complex, with the focus of the problems identified in this study on 3 main aspects, namely the ratio of personnel duties to the area, the ratio of personnel to total population and the ratio of personnel to supporting infrastructure. While efficiency is used to see how easy the public's access to the service system offered is and guarantees or certainty regarding personnel, time and service costs. 
Services performed by the SPKT Polri at the borders have been carried out conventionally, all processes take place in a face to face procedure, meaning that the community comes to the nearest police service post and proposes the desired service or the police's findings in the community is being carried out. The results showed that the level of community satisfaction with this conventional service model was classified as less with a satisfaction index of $60.53 \%$. This happens because there are 8 out of 14 indicators that are judged by the community to have a "less" level of satisfaction.

To anticipate service problems that are less than optimal, a combined service model (online) is built which combines the standard service model (conventional) with the combined service model (online) by inserting technology functions in the service system. The service system is called Dominic's service system. The Dominic service system is built based on the webside, therefore, that there are alternatives for the public to use police services. The results showed that with the application of the online-based service model (website) combined with the conventional service model, it was seen that there was an increase in community satisfaction with border police services. Since the use of Dominic's service model, there are only 2 indicators identified that need to be addressed, while the other 12 indicators are in the good category. The community satisfaction index also increased to $66.32 \%$. The Satisfaction Level Index is specifically reflected in the public perception of the SPKT function in carrying out its Main Duties, which is described as follows:

4.2.1 Effectiveness and efficiency of police report services

The public perception of the effectiveness and efficiency of police reporting services at the border polsek SPKT is described as being that in standard (conventional) services there are $55.5 \%$ of the public who stated that the service was effective. Meanwhile, when the online combined service model was implemented, the number of people who said that services were more effective and efficient increased to $84.4 \%$, or an increase of $28.9 \%$. People who are not united (neutral) towards the effectiveness and efficiency of standard services (conventional) are $36.7 \%$. then when put into the combined service (online) changes to $9 \%$. Or a decrease of $27.7 \%$. Meanwhile, people who stated that standard (conventional) services were not yet effective and efficient were $7.8 \%$. This number then decreased by $1.5 \%$. The decrease in the number of people who do not have an attitude and who think standard (conventional) services are less effective and efficient occurs because they have experienced the benefits of combined services (online) and have contributed to a good perception of the combined (online) service.

\subsubsection{SP2HP Service Effectiveness and Efficiency}

Standard (conventional) service SP2HP or document service of the progress of an investigation results got the perception that the service was effective and efficient by the community at $51.2 \%$. In the combined service model (online) it increased by $33.2 \%$. to $84.4 \%$. People who do not have a (neutral) attitude experience a trend of increasing from $37.9 \%$ to $8.6 \%$ or a decrease of $29.3 \%$ using the combined service model (online) . Meanwhile, people who stated that standard (conventional) services were not yet effective and efficient also experienced a decrease in using the combined service model (online) from $10.9 \%$ to $6.3 \%$ or a decrease of $4.7 \%$.

4.2.3 Effectiveness and Efficiency of SKCK Services

Perceptions of the effectiveness and efficiency of the service model for standard (conventional) services and combined (online) services for SKCK services. The following is the public's perspective which states that standard (conventional) services are effective and efficient at 59.4\%. When the online combined service was implemented, the number of people who stated that the service was effective and efficient increased to $85.5 \%$ or an increase of $26.2 \%$. Meanwhile, on indicators of non-attitudes and community groups stating that the standard (conventional) service model is effective and efficient. experienced a drop of $25 \%$ each from standard (conventional) services of $33.2 \%$ to $8.2 \%$ in the combined Service model (online). And a decrease from $7.4 \%$ to $6.3 \%$ or $1.2 \%$ for service shifting from standard (conventional) services to new model services.

4.2.4 Effectiveness and Efficiency of SIK Services

Public perceptions for the service of crowd permits at border polsek-olsek. that the lam service was effective and efficient at $51.6 \%$. The number of people who perceive that SIK services to be more effective and efficient increased $35.9 \%$ to $87.5 \%$. The number of people who increased their perceptions of the effectiveness and efficiency of the new service model turned out to reduce the percentage of previous service perceptions from the neutral $39.1 \%$ to $6.3 \%$ and those who were still pessimistic with the standard (conventional) service model decreased from $9.4 \%$ to $6.3 \%$.

4.2.5 Effectiveness and Efficiency of SKTLK Services

The effectiveness and efficiency of the combined (online) service model is also seen in the SKTLK service rating of the previous service of $48.4 \%$, increasing to $84.8 \%$. Meanwhile, for a neutral society, there was a decrease from 43.8 to $6.3 \%$. The number of people who are pessimistic on the standard (conventional) service model then becomes optimistic after using the combined service model (online) so that indirectly reduces the quality of its pessimism from $7.8 \%$ to $7.0 \%$.

4.2.6 Effectiveness and Efficiency of STTLP Services

The effectiveness of public services provided by the police SKPT task force at the RI-RDTL border for police report receipt services. The residents who gave a positive perception that the service was effective and efficient 
increased by $32.4 \%$ from $54.7 \%$ in standard (conventional) services to $87.1 \%$ in web-based combined services (online) (online). The number of people who do not have an attitude has shifted their attitude to believe that new services are more effective and efficient. This shift in perception has made the percentage of the number of people who were apathetic to decrease from $35.9 \%$ to only $6.6 \%$ when they already use the combined service model (online). Likewise, the community considered that the SPKT service was ineffective. In the end, after using a webbased online service, the residents changed their decision so that the pessimism decreased from $9.4 \%$ to $6.3 \%$.

The results of the analysis of the Community Satisfaction Index and the public's perception of the effectiveness and efficiency of police services are also supported by the results of hypothesis testing which states that there are significant differences in the effectiveness and efficiency of services from conventional model services to combined model services. The effectiveness and efficiency of services carried out by the SPKT task force at the RI-RDTL border Polsek has increased by $30.18 \%$ from the conventional service model of $53.5 \%$ to $85.6 \%$ when using the website-based combined service model (online).

Two aspects that need to be addressed with regard to the not yet optimal service by using a combined system between the conventional model and the online model are aspects of quality and quantity of officers, as well as fairness of costs. As mentioned above, the ratio of the number of officers to the number of people and the very large area allows an officer to work like a robot. This directly creates ineffectiveness and results in inefficiency of the services provided. Meanwhile, the reasonableness of costs becomes a problem because it is driven by the attitude or character of the officers who are motivated by the motive to take advantage of the situation and position as law enforcers and security service providers for the community.

\section{Conclusion}

Based on the results and discussion, it was concluded that the National Police had done their best to provide public services by even forming a task force that became known as the Integrated Police Service Unit (SPKT). SPKT works based on the principle of excellent service to provide security and law enforcement services to the public in an effective and efficient manner. Implementation of standard SPKT services is only able to provide an index of satisfaction level to the community of $60.53 \%$, where there are 8 out of 14 indicators that still receive a poor rating. SPKT then improves service quality by inputting technology into standard services (conventional) into onlinebased services (combined services) and the results are quite significant after 6 months of use, an increase in the Community Satisfaction Index by $66.32 \%$, leaving only 2 out of 14 indicators still get the less category.

Two less categories that need to be improved are regarding the ability of officers and the fairness of service fees. This condition occurs because the heavy duties and responsibilities of a police officer at the borders have a very high workloads. High workload conditions make officers unprofessional and one of the things that arises is to commit a violation in terms of service fees. The results of hypothesis testing also show that there is a significant difference between the standard service model (conventional) and the combined service model (online) regarding the effectiveness and efficiency of police services at the borders of the Republic of Indonesia and the Democratic Republic of Timor Leste. The results of the study recommend that Dominic's service model as a combined police service model between a standard service model and an online service model is feasible to be used to improve and improve the quality of police services in the Indonesian and RDTL boundaries.

\section{References}

Anton, T. (2002). Terjemahan Buku Police Reacean War. Jakarta: Tunggul Maju.

Basuki, J. (2018). Administrasi Publik: Telaah Teoritis dan Empiris. Depok: Rajawali Pers.

Bayley, D. (1986). Democrazing the Police Abroad: What to Do and How to Do It. New York: National Institute of Justice.

Daton, D. (2020). Hasil Survei Kepatuhan Polres dan Saran Perbaikan Ombudsman. Retrieved April 16, 2020, from Article website: www.ombudsman.go.id/artikel/r/artikel--hasil-survei-kepatuhan-polres-dan-saranperbaikan-ombudsman

Hermawan, H. (2016). Fungsi Kepolisian dalam Pelayanan Publik. Malang: UM Press.

Kapolri. Susunan Organisasi dan Tata Laksana Kepolisian Tingkat Resor dan Kepolisian sektor. , Pub. L. No. No. 3, 2010, 45 (2020). Indonesia.

Liliweri, A. (2014). Sosiologi dan Komunikasi Organisasi. Jakarta: Bumi Aksara.

Luas, J., Kimbal, M., \& Singkoh, F. (2017). Merumuskan Efektivitas Pelayanan Publik di Kelurahan Kakaskasen Dua Kecamatan Tomohon Utara Kota Tomohon. EKSEKUTIF: Jurnal Jurusan Ilmu Pemerintahan, 2(2), $1-12$.

Mahmudi. (2005). Manajemen Kinerja Sektor Publik. Yogyakarta : UPP AMP. YKPN. Mangkunegara

Makmur,H. (2011), Efektifitas Kebijakan Kelembagaan Pengawasan, Bandung : Refika Aditama

Menteri PAN. Pedoman Tatalaksana Pelayanan Umum., Pub. L. No. 81/1993, 13 (1993). Indonesia.

Menteri PAN. Pedoman Umum Penyusunan Indeks Kepuasan Masyarakat., Pub. L. No. KEP/25/M.PAN/2/2004, 22 (2004). Indonesia. 
Monoarfa, H. (2012). Efektivitas dan Efisiensi Penyelenggaraan Pelayanan Publik: Suatu Tinjauan Kinerja Lembaga Pemerintahan. Jurnal Pelangi Ilmu, 5(1), 1-9.

Mulyadi, D. (2015). Perilaku Organisasi dan Kepemimpinan Pelayanan; Konsep dan Aplikasi Administrasi, Manajemen dan Organisasi Modern. Bandung: Alfabeta.

Presiden RI. Undang-Undang Republik Indonesia Nomor 2 Tahun 2002 tentang Kepolisian Negara Republik Indonesia. , (2002). Indonesia.

Sugiyono, S. (2012). Statistika untuk Penelitian. Bandung: Alfabeta.

Zauhar, S. (2007). Reformasi Administrasi. Jakarta: Bumi Aksara. 